\title{
Influence of maize straw content with sewage sludge on composting process
}

\author{
Wojciech CZEKALA ${ }^{\text {ABCDEF }}$, Jacek DACH ${ }^{\text {ABDEF }}$, Damian JANCZAK ${ }^{\text {ABD }}$, \\ Anna SMURZYŃSKA ${ }^{\text {BCD }}$, Agnieszka KWIATKOWSKA ${ }^{\text {BEF }}$, \\ Kamil KOZLOWSKI ${ }^{\text {EF }}$
}

Poznań University of Life Sciences, Faculty of Agronomy and Bioengineering, ul. Wojska Polskiego 28, 60-637 Poznań, Poland; e-mail: wojciech@up.poznan.pl

For citation: Czekała W., Dach J., Janczak D., Smurzyńska A., Kwiatkowska A., Kozłowski K. 2016. Influence of maize straw content with sewage sludge on composting process. Journal of Water and Land Development. No. 30 p. 43-49. DOI: 10.1515/jwld-2016-0020.

\begin{abstract}
After entrance to EU in 2004, the management of sewage sludge has become more and more important problem for the new members. In Poland, one of the most promising technologies is composting process of sewage sludge with carbonaceous materials. However, the high price of typically used cereal straw forces the specialists to look for new and cheap materials used as donor of carbon and substrates creating good, porous structure of composted heap. This work presents the results of sewage sludge composting mixed with sawdust and maize straw used to create structure favorable for air exchange. The results show dynamic thermophilic phase of composting process in all cases where maize straw was used.
\end{abstract}

Key words: composting process, maize straw, sewage sludge, waste management

\section{INTRODUCTION}

The amount of produced sewage sludge has been constantly increasing along with the development of humanity, improvement of sewage sludge treatment technology and increased sewerage level of developed and developing countries [SINGH, AGRAWAL 2008]. This type of waste can be implemented as organic fertilizer, valuable in nitrogen and others macronutrients [CHENG et al. 2007]. However, taking into account numerous requirements of environmental management, sewage sludge become a problem [HARRISON et al. 2006; KHADHAR et al. 2010]. An unfavorable feature of this waste is specific, amorphous structure, which favors anaerobic decomposition and production of gases harmful for health and environment such as ammonia, hydrogen sulfide, aromatic hydrocarbons and others. The most problematic issue concerning sewage sludge is their sanitary conditions and lack of stability. In order to reduce this negative factor, the discussed waste can be composted within presence of clear thermophilic phase [WÉRY et al. 2008]. In consequence, the sewage sludge will be subjected hygienisation and obtained compost will be a stable, fully environmental friendly fertilizer. However, it is extremely important to maintain the proper $\mathrm{C}: \mathrm{N}$ ratio in order to run the composting process in the right direction. Lack of corresponding relations between these elements perturbs the composting process and causes the emission of gases harmful to nenvironment. The optimal $\mathrm{C}: \mathrm{N}$ ratio at the beginning of the process should amount 20-30 [PAKOU et al. 2009]. Sewage sludge because of high content of nitrogen (approx. $50 \mathrm{~g} \mathrm{~N} \cdot \mathrm{kg}^{-1}$ d.m.) become a difficult material for composting. Addition of different materials with high 
carbon content (like different kind of straw, sawdust) can be used in order to support the possibility of aerobic decomposition [HIMANEN, HÄNNINEN 2011]. Its amount permits to extend the relation which causes better conditions for the process initiation. Materials useful for increase of the carbon amount can be straw and sawdust. Another valuable straw feature is creation of the structure. It allows the proper pile's oxygenation which in turn can prevent the occurrence of anaerobic conditions and finally contributes to more rapid degradation [SUNDBERG, JÖNSSON 2008].

Obviously for economic reasons, there is no possibility that any sewage sludge composting plant could function rationally if the mass of sewage sludge (measured in dry mass) would be lower than mass of carbon additives (straw or sawdust) because of high market price.

However it should be remembered that composting process of the material with low initial $\mathrm{C}: \mathrm{N}$ ratio is a guarantee of the strong ammonia emission [AMON et al. 1998]. Moreover the deficiency of structural materials rich in carbon is the reason of faster collapse of the pile and creation of anaerobic conditions leading to the emissions of hydrogen sulfide, methane and odors. Towards the commonly observed on national composting plants tendencies to reduce the mass of applied organic materials with high carbon content, raises the question what is an acceptable level of additive, where ammonia emission during composting process is on the acceptable level and leads to nitrogen losses not exceeding $10-12 \%$ (level in properly conducted manure composting process).

\section{RESEARCH AIM}

The aim of the study was to compare the composting process run (with special regard of gaseous emissions) of sewage sludge mixed in different proportions with maize straw and sawdust, under controlled laboratory conditions using specialized research equipment (isolated 4-chamber bioreactor) and standard research methodology. The work was realized in the frame of the project financed by the Polish Ministry of Science and Higher Education N N310 225033 entitled "Technology of harvest and storage of maize straw as an energy biomass and structural substrate for composting process".

\section{MATERIALS AND METHODS}

The studies on sewage sludge composting process were carried out during 2011 in Ecotechnologies Laboratory at Institute of Biosystems Engineering (Poznań University of Life Sciences, PULS). In the experiment 4-chamber isothermal bioreactor was used (Fig. 1). It was constructed in 2002-4 in the frame of ministerial grant entitled "Gaseous emissions in different technologies of manure management" [DACH 2005] and then rebuilt during the realization of the project within $6^{\text {th }}$ European Union Framework Program "Technology of compost production from sewage sludge with reduction of ammonia emission and heavy metal content" (acronym CleanCompost).

As a part of these projects, a number of comparative studies have been carried out and it has been stated that the bioreactor truly reproduces composting processes running in the real conditions, and in particular long, few weeks lasting thermophilic phase. Such a dynamic thermophilic phase with temperature exceeding $70-75^{\circ} \mathrm{C}$ is typical for research conducted under real conditions [WOLNA-MARUWKA, DACH 2009].

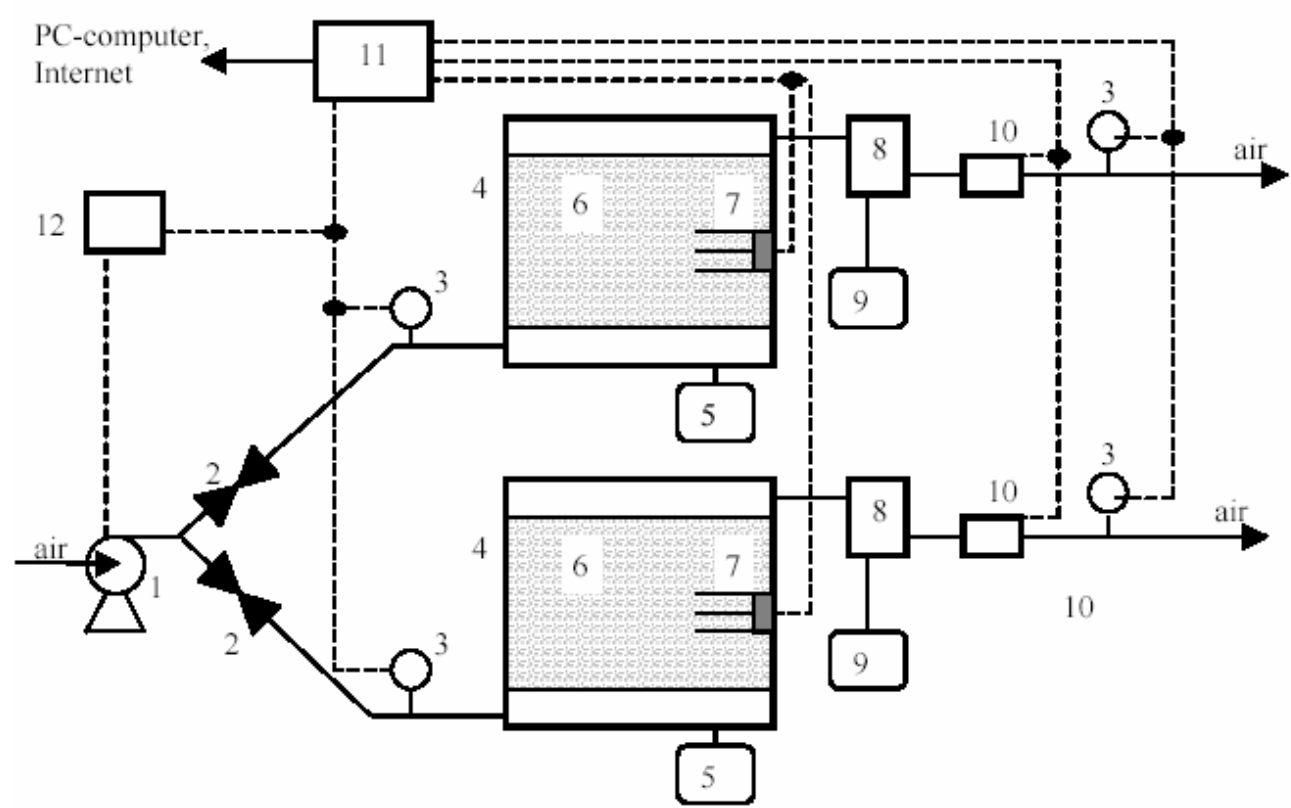

Fig. 1. Schematic diagram of the 2-chamber bioreactor: 1 - pump, 2 - flow regulator, 3 - flow meter, 4 -isolated chamber, 5 - drained liquids container, 6 - composted mass, 7 - sensors set, 8 - air cooling system, 9 - condensates container, 10 - column of gases content analysis $\left(\mathrm{NH}_{3}, \mathrm{O}_{2}, \mathrm{CO}_{2}, \mathrm{CH}_{4}, \mathrm{H}_{2} \mathrm{~S}\right), 11$-16-channel recorder, 12 - air pomp steering system; source: own elaboration 
Tested sewage sludge was taken from a sewage sludge treatment plant in Szamotuły near Poznan. It is typical small installation producing 5-7 thous. $t$ of sewage sludge per year. This kind of biological treatment plants is very common in Poland, there are more than 1500 units. Sewage sludge from Szamotuły treatment plant was used as an agricultural fertilizer, but because of changing legal requirements in Poland since 2013 it will be impossible to use this kind of sludge without its processing and certification in accredited laboratory. Hence occurred a need for sewage sludge treatment technologies, where the composting seems to be the most environmental favorable and the cheapest one. It is worth to highlight that sewage sludge were collected from the typical wastewater treatment plant in a small town (40 000 inhabitants) with lack of heavy industry and sewage sludge have a minimum content of heavy metals.

The mixtures of sewage sludge $(75,60,45$ and $30 \%$ of dry mass in particular chambers $\mathrm{K} 1, \mathrm{~K} 2, \mathrm{~K} 3$ and K4) and 5\% maize straw have been prepared in order to investigate. The rest was a hardwood sawdust complement from the carpenter of Faculty of Wood Technology (PULS). As a structural material for research the maize straw has been chosen because it is a cheap material (below 12 euro $\mathrm{t}^{-1}$ ), commonly available, giving better effects in composting in relation to traditionally used cereal straw (price in Poland above 40 euro $\left.^{-1} \mathrm{t}^{-1}\right)$.

After mixing and sampling for the analyses, sewage sludge mixtures were placed in isolated bioreactor chambers and then undergo the composting process. The precise analysis of the mixtures initial parameters is shown in Table 1.

Table 1. The content of mixtures prepared for composting calculated in dry matter

\begin{tabular}{|c|c|c|c|}
\hline Mixture & Sewage sludge, $\%$ & Sawdust, $\%$ & Straw, $\%$ \\
\hline SS_75\% & 75 & 20 & 5 \\
\hline SS_60\% & 60 & 35 & 5 \\
\hline SS_45\% & 45 & 50 & 5 \\
\hline SS_30\% & 30 & 65 & 5 \\
\hline
\end{tabular}

Source: own study.

It is worth to highlight that in order to compensate the level of initial humidity in composted mixtures to the level of the mixtures $\mathrm{SS} 45 \%$ and SS $30 \%$, the water has been added (respectively 8 and $18 \mathrm{dm}^{3}$ ). It was necessary because as a result of the reduced content of sewage sludge in SS_45\% and SS $30 \%$, the humidity level would be even twice lower than in SS 75\%, making difficult comparison of research results and their reference to the real conditions (initial humidity at the level of $60 \%$ which is very rare in composting plants and it usually varies between $70-80 \%$ ). The sewage sludge in all chambers were aerated by the air flow of $3.5 \mathrm{dm}^{3} \cdot \mathrm{min}^{-1}$. Two types of chemo-electrical sensors MG-72 (scale 0-1000 ppm) from Alter S.A. firm have been used in the experiments [BONIECKI et al. 2012]. The gauge
Metex M3870D allowed to read the data subsequently. The temperature variation was registered by means of temperature sensors connected to 16channel recorder and read manually during the gaseous measurement. The air flow through the bioreactor chambers was adjusted manually using the rotameter (flow readability of $0.05 \mathrm{dm}^{3} \cdot \mathrm{min}^{-1}$ ), whereas the constant control was by means of electronic flow sensors and connected to the register. Moreover the amount of air flow was also measured with analog counters.

The physical as well as chemical analyzes (dry matter, organic dry matter, $\mathrm{pH}, \mathrm{C}_{\text {org }}, \mathrm{N}_{\text {tot }}, \mathrm{N}^{-\mathrm{NH}_{4}}$ ) were made at PULS laboratories with the standard procedures [PIOTROWSKA-CYPLIK et al. 2009; WOLNA-MARUWKA et al. 2009].

\section{RESULTS}

Comparison of the initial parameters of all studied mixtures are presented in Table 2. In experiment $\mathrm{C}$ : $\mathrm{N}$ ratio is in the range 9.2-26.4 which was dependent on the ratio of sewage sludge (rich in nitrogen) with sawdust (rich in carbon) (Tab. 2).

Table 2. Basic physical and chemical parameters of the composted mixtures

\begin{tabular}{|l|c|c|c|c|}
\hline \multicolumn{1}{|c|}{ Parameter } & SS_75\% & SS_60\% & SS_45\% & SS_30\% \\
\hline Fresh mass, kg & 60.2 & 50.2 & 44.2 & 48.2 \\
\hline Dry mass, kg & 11.20 & 12.60 & 11.23 & 12.53 \\
\hline Humidity, \% & 81.5 & 74.9 & 74.6 & 74.0 \\
\hline Density & 506.82 & 380.57 & 327.75 & 431.91 \\
\hline C:N ratio & 9.2 & 12.1 & 17.0 & 26.4 \\
\hline O.M. & 90.0 & 88.7 & 90.3 & 86.8 \\
\hline
\end{tabular}

Explanations: SS $75 \%$, SS $60 \%$, SS $45 \%$, SS $30 \%$ as in Table 1 . Source: own study.

The higher density of mixture SS_30\% than SS $45 \%$ was related with watering of material prepared for composting. Because of large content of sawdust, without additional water input this mixture should be too dry for composting and whole process could be incomparable to the other mixtures.

\section{TEMPERATURE CHANGES}

One of the basic parameters testifying the possibility of normal composting process run is to obtain the appropriate temperatures during the experiment. It is necessary to occurrence of thermophilic phase with temperatures exceeding $70^{\circ} \mathrm{C}$. The temperature courses in the investigated composts are shown in Figure 2.

In all four tested mixtures it has been significantly exceeded the level of $70^{\circ} \mathrm{C}$, which is considered as an indispensable for hygienisation and sanitation of composted wastes. The highest temperature $81.3^{\circ} \mathrm{C}$ was achieved on the third day in compost SS_60\%. Analyzing the data on Figure 2 it can be stated that in each compost there were all 4 phases of the composting process. An intense thermophilic phase (phase 2) undoubtedly occurred in all four mix- 
tures undergoing the decomposition process under aerobic conditions.

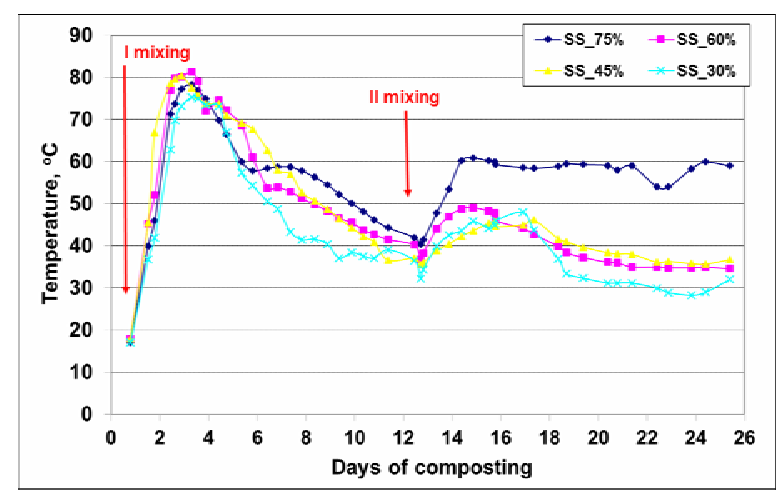

Fig. 2. Temperatures of the mixtures during the experiment; SS_75\%, SS_60\%, SS_45\%, SS_30\% as in Table 1; source: own study

On the $12^{\text {th }}$ day of the process the second mixing took place (simulation of tractor aerator passage throughout composting pile in real scale process). The aim was to improve the material structure and facilitate oxygen transfer as well as increase of the organic materials decomposition period. And the next day the effects were visible as evidenced by the temperature increase lasting several next days. Definitely the most favorable effect was observed in the compost with the highest content of sewage sludge. This mixture temperature amounted $60.9^{\circ} \mathrm{C}$. Since the 22 day of composting process the temperature in all four chambers started to stabilized, that proved an initiation of the last composting phase - maturity one (Fig. 2).

Figure 3 presents the course of cumulative temperature for selected mixtures for the whole experiment period. There was kind of dependence between this and the mixtures content. Cumulative temperatures were increasing along with the growth of the sewage sludge content in the mixture (Fig. 3).

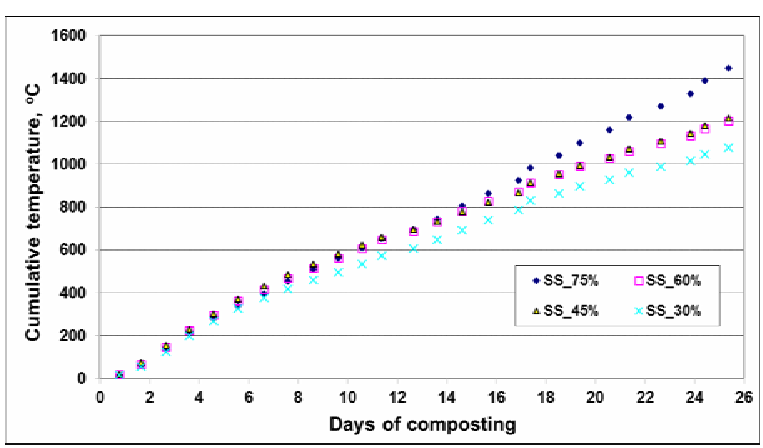

Fig. 3. Cumulative temperature in studied mixtures during composting process; SS_75\%, SS_60\%, SS_45\%, SS_30\% as in Table 1; source: own study

It can be noticed that the strongest increase of temperature was in case of mixture SS_75\%, and the weakest for SS_30\%. Apparently the mass dominant fraction of sawdust with the lowest nitrogen content did not foster an intense heating of the mixture.

\section{DYNAMICS OF OXYGEN CHANGES IN THE BIOREACTORS}

The oxygen content is one of most decisive factors of oxygenic decomposition which is directly related to compost self-heating properties as well as other gases emissions. The proper content of this gas (more than $10 \%$ ) creates the possibility for organic matter decay without fermentation process. Taking into account the nature of this parameter, it was measured twice a day and directly after aeration three times. At the beginning of the experiment its content in bioreactors amounted about $21 \%$, which was identical with its amount in the atmosphere (Fig. 4). Since the second day of the experiment its amount started to decrease rapidly, yet the amount of carbon dioxide was increasing. This is related with the presence of thermophilic phase in composts. Along with the temperature stabilization the oxygen amount was decreasing, which indicated the reduction of time of organic matter decomposition. Stabilization at the level of $20-22 \%$ occurred in all chambers on the 23 day of experiment that is along with initiation of maturity phase (Fig. 4).

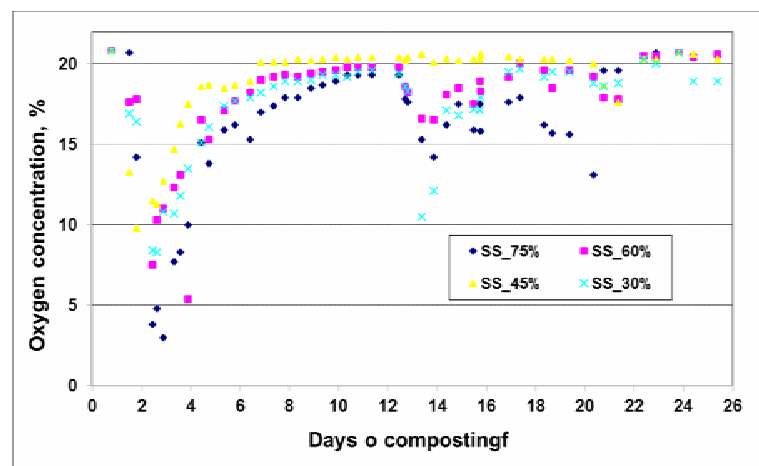

Fig. 4. Oxygen concentration in studied mixtures during composting process; SS_75\%, SS_60\%, SS_45\%, SS_30\% as in Table 1; source: own study

During the whole period of the experiment the air flow was under control, so that there were no anaerobic conditions. The changes depended on oxygen concentration inside the chamber (Fig. 4). The oxygen content level less than 5\% was assumed as the beginning of the anaerobic zone, while the level of $8 \%$ required more attention. Maximum air flow was 5 liters per minute, and was set with relate to the oxygen level in the bioreactor (Fig. 5). Average air flow amounted between $2.95 \mathrm{dm}^{3} \cdot \mathrm{min}^{-1}$ for compost $\mathrm{SS} 75 \%$ up to $2.7 \mathrm{dm}^{3} \cdot \mathrm{min}^{-1}$ for compost SS_30\% (Fig. $\overline{6}$ ).

\section{DYNAMICS OF $\mathrm{CO}_{2}$ AND AMMONIA CHANGES IN BIOREACTORS}

Carbon dioxide emission was caused by organic matter decomposition. Increase of $\mathrm{CO}_{2}$ in the exhausted gases proves the proper decomposition of sawdust, 


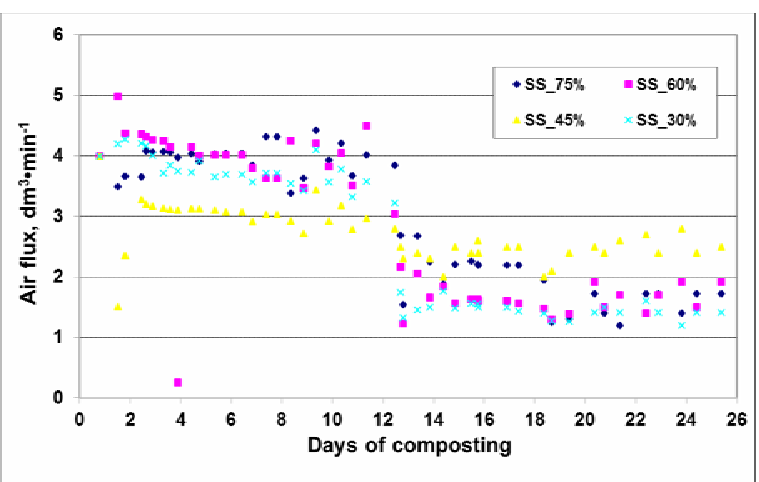

Fig. 5. Air flow daily measurements in studied mixtures; SS_75\%, SS_60\%, SS_45\%, SS_30\% as in Table 1; source: own study

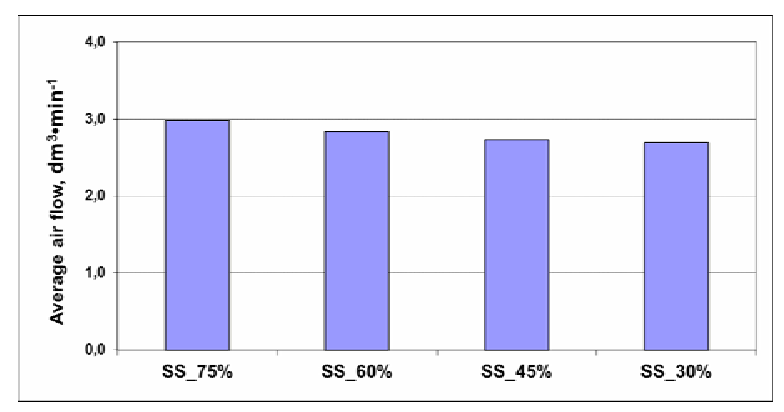

Fig. 6. Average air flow for studied mixtures;

SS_75\%, SS_60\%, SS_45\%, SS_30\% as in Table 1 ; source: own study

straw and sludge, the materials with high carbon content. From the moment of maximum temperatures occurrence in all four bioreactors a strong decrease of carbon dioxide was noticed, which graph was exponential. Only aeration made on $12^{\text {th }}$ composting day of the experiment has initiated another increase in the decomposition intensity, which was proved by the growth of the content of discussed gas in exhausted gases mixture. What is interesting after second aeration the highest $\mathrm{CO}_{2}$ level, amounting $10.3 \%$ was noted in compost SS_30\%, the one with the lowest content of sewage sludge (Fig. 7).

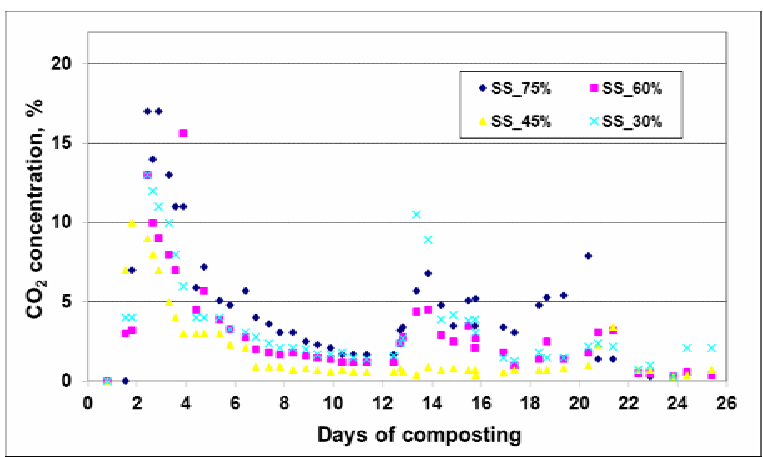

Fig. 7. $\mathrm{CO}_{2}$ emission in gasses emitted from bioreactors; SS_75\%, SS_60\%, SS_45\%, SS_30\% as in Table 1; source: own study

Ammonia was the last tested gas in the composts. Although the emission range of the discussed gas amounted from 0 to $1476 \mathrm{ppm}$ its size is an im- portant parameter. It is related with the fact that agriculture is an important producer of ammonia, which passing into the atmosphere makes worse its quality. The emission amount of the discussed inorganic nitrogen compound is closely related to the content of the sewage sludge in the compost. Thus, the highest emissions were recorded in heaps SS_75\% and SS_60\% (Fig. 8).

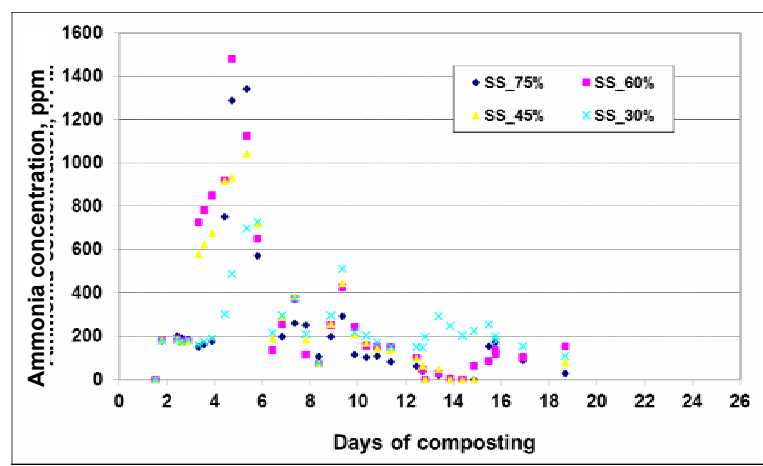

Fig. 8. Ammonia emission in gasses emitted from bioreactors; SS $75 \%$, SS $60 \%$, SS $45 \%$, SS $30 \%$ as in Table 1; source: own study

Similarly as in case of $\mathrm{CO}_{2}$ emission the highest ammonia emissions were noted during the thermophilic phase and immediately thereafter, regardless the initial mixture. The highest cumulative ammonia emissions occurred in compost SS_60\% and the lowest in SS_45\% (Fig. 9).

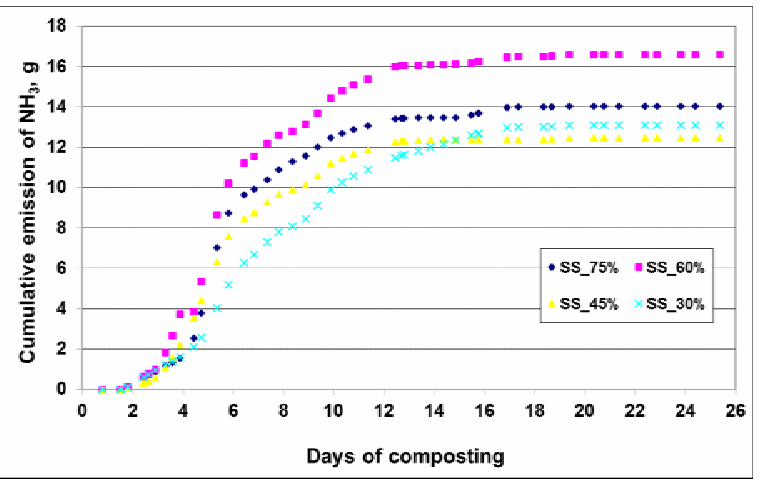

Fig. 9. Cumulative ammonia emission in gasses emitted from bioreactors; SS_75\%, SS_60\%, SS_45\%, SS_30\% as in Table 1; source: own study

It has to be underline that important amount of nitrogen were also found in leakages, especially in case of SS_75\% and SS-60\%.

\section{DYNAMICS OF CHANGES OF COMPOSTED MIXTURE FRESH MASS}

A typical phenomenon for the composting process is the loss of mass along with the experiment duration. Although the fresh mass of the composted mixtures were significantly different (Tab. 2), however it was possible to compare the dynamics of changes on the basis of the percentage content before and after the experiment. 
The largest mass loss occurred in the compost with the highest content of sewage sludge (SS 75\%), which was caused by high water content in this component of the mixture (Fig. 10). In the rest of the heaps there was also a considerable mass loss, however it was not as significant as in compost SS 75\%, and amounted at the level of $26-27 \%$.

The mass losses from composted mixtures occurred mainly throughout gaseous way in consequence of water vaporization and $\mathrm{CO}_{2}$ emitted during OM decomposition. The leachates collected from bioreactor chambers were lower than $1550 \mathrm{~g}$ for all mixtures except SS_30\% which produced 2381 g of leachate, mainly during first day of experiment, as a result of strong artificial watering of mixture contained large amount of dry sawdust.

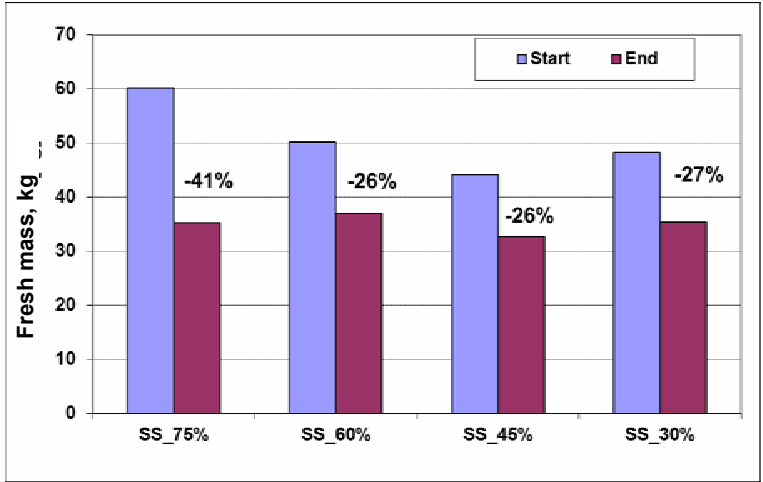

Fig. 10. Strong reduction of the composted mixture fresh mass; SS $75 \%$, SS $60 \%$, SS $45 \%$, SS $30 \%$ as in Table 1 ; source: own study

\section{CONCLUSIONS}

1. All studied mixtures have passed through the long and significant thermophilic phase and reached maximum temperature over $75^{\circ} \mathrm{C}$. With almost the same aeration level and similar initial dry mass, the cumulative temperature was the highest in SS 75\% mixture and the lowest in SS 30\% which suggests that sewage sludge content is important factor of compost self-heating.

2. The highest cumulative temperature in SS $75 \%$ is related with the deepest losses of fresh mass in this mixture by $41 \%$. The mass losses were related with water vaporization and $\mathrm{CO}_{2}$ from organic matter decomposition.

3. The deep fall of oxygen content and strong $\mathrm{CO}_{2}$ emission during the period of the highest temperature of composted mixtures (between $2^{\text {nd }}$ and $5^{\text {th }}$ day) suggest the needs of higher aeration within initial period of decomposition. However, the effect of temperature growth after second mixing of composted materials has been noticed.

4. The ammonia content in exhausted air was very high in all studied mixtures (from $730 \mathrm{ppm}$ for SS_30\% to $1480 \mathrm{ppm}$ for SS_60\%). However, the important losses were also found in leachates collected during the experiment.

\section{Acknowledgements}

This work was supported by Polish Ministry of Science and Higher Education under the grant no. N N313 270938 "Harvesting and storage technology of maize straw as biomass energy and structural material for composting".

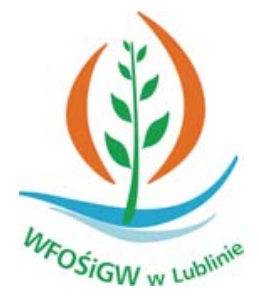

Dofinansowano ze środków

Wojewódzkiego Funduszu Ochrony Środowiska

i Gospodarki Wodnej w Lublinie

Cofinanced by Voivodeship Fund

for Environmental Protection

and Water Management in Lublin

\section{REFERENCES}

Amon B., Amon T., Boxberger J., Pollinger A. 1998. Emissions of $\mathrm{NH}_{3}, \mathrm{~N}_{2} \mathrm{O}$ and $\mathrm{CH}_{4}$ from composted and anaerobically stored farmyard manure. $8^{\text {th }}$ International Conference on Management Strategies for Organic Waste Use in Agriculture. Rennes, France, 26-29 May 1998 p. 209-216.

Boniecki P., Dach J., Pilarski K., PieKarsKa-Boniecka H. 2012. Artificial neural networks for modeling ammonia emissions released from sewage sludge composting. Atmospheric Environment. Vol. 57 p. 49-54.

DACH J. 2005. Polish experience with ammonia emission abatement for straw-based manure. In: Emissions from European agriculture. Wageningen Academic Publishers p. $295-303$

Cheng H.F., Xu W.P., LiU J.L., ZhaO Q.J., He Y.Q., CheN G. 2007. Application of composted sewage sludge (CSS) as a soil amendment for turfgrass growth. Ecological Engineering. Vol. 29. Iss. 1 p. 96-104.

HARRISON E.Z., OAKES S.R., HYSELl M., HAY A. 2006. Organic chemicals in sewage sludges. Science of the Total Environment. Vol. 367. Iss. 2-3 p. 481-497.

Himanen M., HÄNNINEN K. 2011. Composting of bio-waste, aerobic and anaerobic sludges-effect of feedstock on the process and quality of compost. Bioresource Technology. Vol. 102. Iss. 3 p. 2842-2852.

Khadhar S., Higashi T., Hamdi H., Matsuyama S., Charef A. 2010. Distribution of 16 EPA-priority polycyclic aromatic hydrocarbons (PAHs) in sludge collected from nine Tunisian wastewater treatment plants. Journal of Hazardous Materials. Vol. 183. Iss. 1 p. 98102.

Pakou C., Kornaros M., Stamatelatou K., Lyberatos G. 2009. On the fate of LAS, NPEOs and DEHP in municipal sewage sludge during composting. Bioresource Technology. Vol. 100. Iss. 4 p. 1634-1642.

Piotrowska-Cyplik A., Olejnik A., Cyplik P., Dach J., CZARNECKI Z. 2009. The kinetics of nicotine degradation, enzyme activities and genotoxic potential in the characterization of tobacco waste composting. Bioresource Technology. Vol. 100. Iss. 21 p. 5037-5044.

Singh R.P., AGRAwaL M. 2008. Potential benefits and risks of land application of sewage sludge. Waste Management. Vol. 28. Iss. 2 p. 347-358.

SundBERG C., JÖNSSON H. 2008. Higher $\mathrm{pH}$ and faster decomposition in biowaste composting by increased aeration. Waste Management. Vol. 28. Iss. 3 p. 518-526.

WÉry N., LHOUTEllier C., DuCRAy F., DelgenÈs J.P., GoDON J.J. 2008. Behavior of pathogenic and indicator 
bacteria during urban wastewater treatment and sludge composting, as revealed by quantitative PCR. Water Research. Vol. 42. Iss. 1-2 p. 53-62.

Wolna-MaruwKa A., Dach J. 2009. Effect of type and proportion of different structure-creating additions on the inactivation rate of pathogenic bacteria in sewage sludge composting in a cybernetic bioreactor. Archives of Environmental Protection. Vol. 35. Iss. 3 p. 87-100.

Wolna-Maruwka A., Dach J., Sawicka A. 2009. Effect of temperature on the number of selected microorganism groups and enzymatic activity of sewage sludge composted with different additions in cybernetic bioreactors. Agronomy Research. Vol. 7. Iss. 2 p. 875-890.

\section{Wojciech CZEKALA, Jacek DACH, Damian JANCZAK, Anna SMURZYŃSKA, Agnieszka KWIATKOWSKA, Kamil KOZLOWSKI}

\section{Wpływ zawartości słomy kukurydzianej oraz osadów ściekowych na proces kompostowania}

\section{STRESZCZENIE}

Po przystapieniu Polski do Unii Europejskiej w 2004 r. gospodarka osadami ściekowymi stała się dla nowych państw istotnym problemem. W Polsce jedną z najbardziej obiecujących technologii jest kompostowanie osadów ściekowych wraz z substratami bogatymi w węgiel. Jednakże wysoka cena słomy zbożowej stwarza konieczność poszukiwania tanich materiałów bogatych w węgiel i poprawiających porowatość kompostowanej pryzmy. W pracy zaprezentowano wyniki badań nad kompostowaniem osadów ściekowych z dodatkiem trocin oraz słomy kukurydzianej, używanej jako substrat umożliwiający lepszy przepływ powietrza. Doświadczenie zostało przeprowadzone w bioreaktorach do modelowania procesu kompostowania będących na wyposażeniu Instytutu Inżynierii Biosystemów. Wyniki dowiodły, że wystąpiła dynamicznie faza termofilna w każdej z prób, w której używano słomy kukurydzianej.

Słowa kluczowe: gospodarka odpadami, osady ściekowe, proces kompostowania, słoma kukurydziana 